\title{
Facile and controlled production of silver borate nanoparticles
}

\author{
Osman Aguş ${ }^{1} \cdot$ Yüksel Abalı $^{1}\left[\right.$ D $\cdot$ Osman Arslan ${ }^{2} \cdot$ Nalan Oya San Keskin ${ }^{3}$
}

(c) Springer Nature Switzerland AG 2019

\begin{abstract}
Nanosized silver (Ag) borate particles were synthesized under facile and controlled conditions for the antibacterial ceramic applications. Obtained powder materials were characterized comprehensively for the detection of crystallinity, particle size, morphology and surface characteristics. Since obtained borate particles must be optimized by comparing their size, shape and composition, a statistical method (Taguchi Method) was used. Taguchi method allowed the control and deep insight on the variables namely temperature, reaction time, mol ratio and stirring speed. Since obtained nanoparticles can be easily modified and dispersed in ceramic matrixes, formation parameters for the best antibacterial glaze composition were defined. Structural analysis and crystallinity investigation with x-ray diffraction showed that temperature has a huge impact on the formation of nanoparticles as diffraction patterns revealed. Scanning Electron Microscopy unveiled that morphology of the nanoparticles are relatively spherical and EDX revealed that there is no other impurities. Synthesized nanoparticles were utilized for the $1 \times 1 \mathrm{~cm}$ ceramic samples for antibacterial applications. Results showed that gram positive and gram negative bacterias are deactivated as tests revealed and reported.
\end{abstract}

Keywords Silver borate $\cdot$ Nanoparticles $\cdot$ Ceramic coating $\cdot$ Antibacterial nanomaterial

\section{Introduction}

Enhancement of the bacterial infections in our daily life, requires the production of facile and active antibacterial agents [1]. Therefore, the synthesis and industrial development of environmentally friendly products are escalating [2-7]. As known, antibacterial compositions are exploited in medical applications [8, 9], food industry [10], cosmetic products [11], water treatment [12], agriculture application [13] and in fields that prevent the destruction and spread of microorganisms.

Mostly silver, zinc, copper, mercury, titanium are the main columns of the antibacterial structures [14]. These metal ions inhibit bacterial enzymes by contact and penetration which prevents the bacteria from negative propagations [15]. Among these compositions, nanoparticles represent a crucial class which is produced by facile and environmentally friendly methods. Since antibacterial nanoparticles can be manifested from metals [16], metal oxides [17], metal salts [18, 19], metal hydroxides [20], and polymers, one can optimize the production technology by optimizing the formation conditions [21]. Even though various antibacterial agents which contains silver $[22,23]$, gold [24] and zinc [25] were exerted, the ionic silver seems more suitable since it provides the highest antibacterial activity against bacterial infections [26-28].

Silver is recognized as antibacterial for centuries [29-31] and silver containing compounds are used as antibacterial practices due to its availability and extreme resistance against to bacterial infections [32-34].

Electronic supplementary material The online version of this article (https://doi.org/10.1007/s42452-019-0686-y) contains supplementary material, which is available to authorized users.

Yüksel Abalı, yabali@yahoo.com | 'Department of Chemistry, Faculty of Science and Letters, Celal Bayar University, 45140 Manisa, Turkey. ${ }^{2}$ Food Engineering Department, Faculty of Engineering and Natural Sciences, İstanbul Sabahattin Zaim University, 34303 Istanbul, Turkey. ${ }^{3}$ Biology Department, Polatlı Science and Literature Faculty, Ankara Hacı Bayram Veli University, 06900 Polatlı, Ankara, Turkey.

SN Applied Sciences (2019) 1:662 | https://doi.org/10.1007/s42452-019-0686-y 
Therefore even nowadays, silver containing items are seen in diverse applications such as wound healing [35], eye infections [36, 37], and aspirative infections due to katherer [38, 39]. Enormous activity of silver arises from $[40,41]$ the cellular level activity of the silver cations. Mechanisms revealed that the interaction of $\mathrm{Ag}^{+}$with respiratory and transport proteins might be one of the reasons $[42,43]$. In addition to that inhibition of proliferative ability of bacterial cells exposed to $\mathrm{Ag}^{+}$should also be taken into account [40].

In previous studies, Sadeghnejad et al. [44]. coated the silver nanoparticles on the polyethylene film with the polymer-particle (Polyethylene-Ag) approach and tested this hybrid coating against Staphylococcus aureus and Escherichia coli bacteria. As a result of this work, it has been stated that the antibacterial polyethylene films can be utilized for food packaging and storage. Magyari et al. [45] synthesized bioactive $10 \mathrm{~B}_{2} \mathrm{O}_{3}-30 \mathrm{Na}_{2} \mathrm{O}-60 \mathrm{P}_{2} \mathrm{O}_{2}$ glass with antibacterial properties. Found that the product containing $\mathrm{Ag}_{2} \mathrm{O}$ in the range of $0.2-1 \mathrm{~mol} \%$ showed more antibacterial properties than the product containing $\mathrm{Ag}_{2} \mathrm{O}$ in $1.5 \mathrm{~mol} \%$ and $2 \mathrm{~mol} \%$. Jaiswal et al. [46] added silver, copper and zinc ( $\mathrm{Ag}, \mathrm{Cu}, \mathrm{Zn}$ ) Nitrate into methyltriethoxysilane and coated with polyethylene plate. After the antibacterial test, it was found that the product containing $\mathrm{Ag}+$ is more antibacterial than the others. Panico et al. [12]. have investigated the antibacterial endurance of silver water filters and their potential application in the reduction of bacterial fouling and proliferation in water treatment. Poly(ether sulfone) membranes commonly used in water filtration were coated with silver nanoparticles synthesized via in situ photo reduction method. De Simone et al. [13] have developed antibacterial silver-coated HDPE nets for an innovative application such as agriculture. Antibacterial coatings on high-density polyethylene nets were obtained by a patented nanosilver deposition technique based on the in situ photo-reduction of a silver solution. According to these investigations different form of silver can be a source for the antibacterial investigations.

Depending on the previous investigations, we have statistically studied controlled facile synthesis of Silver (Ag) Borate nanoparticles by Taguchi method. Obtained nanoparticles were analysed and best parameters were detected for the facile, stable and industrial scale synthesis of silver borate nanoparticles. Especially, size, reaction temperature and surface characteristics of the obtained nanoparticles were investigated and it was revealed that the synthesis of these nanoparticles can be modelled and standardized for industrial scale. Additionally obtained nanoparticles can be utilized as an antibacterial agent for the ceramic glaze applications and exhibits remarkable reactivity for the ceramic applications.

\section{Materials and methods}

\subsection{Materials}

Disodium Tetraborate Decahydrate $\left(\mathrm{Na}_{2} \mathrm{~B}_{4} \mathrm{O}_{7} \cdot 10 \mathrm{H}_{2} \mathrm{O}\right)$ (Merck) and Silver Nitrate $\left(\mathrm{AgNO}_{3}\right.$ ) (Nalgene) were used for the statistical silver borate nanoparticles synthesis. Both materials were used without further purification.

\subsection{Synthesis of silver borate nanoparticles NP}

Silver nitrate $\left(\mathrm{AgNO}_{3}\right)$ and Borax $\left(\mathrm{Na}_{2} \mathrm{~B}_{4} \mathrm{O}_{7} \cdot 10 \mathrm{H}_{2} \mathrm{O}\right)$ were reacted at different temperatures with varying molar ratios of $\mathrm{AgNO}_{3} / \mathrm{Na}_{2} \mathrm{~B}_{4} \mathrm{O}_{7} \cdot 10 \mathrm{H}_{2} \mathrm{O}$. Additionally reaction time was also varied. Whole procedures can be found at (Supporting Table 1). Figure 1 represents the obtained Silverborate nanoparticles. During the reflux procedure, after the addition of borax into the silver solution, an immediate formation nucleation was observed. After the nucleation and growth, with the help of reaction conditions we obtained silver borate nanoparticles which was examined by XRD and SEM for further applications. Nanoparticles were washed and dried with EtOH before the analysis.

\subsection{Characterization}

The morphology and atomic analysis with size detection of the nanoparticles were observed using (SEM) scanning electron microscopy and EDX. Observed nanoparticles were dispersed in $\mathrm{EtOH}$, ultrasonicated and then one drop of this solution was placed onto $\mathrm{Cu}$ tape. $5 \mathrm{~nm}$ of Au was coated for enhancing the imaging quality. Surface characteristics were characterized with FT-IR spectrometer on Agilent 600 series ATR module Spectrophotometer. The wave number ranges from 4,000 to $500 \mathrm{~cm}$ at a resolution of $4 \mathrm{~cm}^{-1}$. Crystallinity properties of these nanoparticles were obtained by XRD - Philips X'Pert Pro between $2 \theta=20-80$. Thermal properties and observation was realized using TGA Shimadzu DTG-60 series with temperature rate $20^{\circ} \mathrm{C} / \mathrm{min}$ till $1000^{\circ} \mathrm{C}$. Optical behaviours of the obtained nanoaprticles were examined with UV-Vis

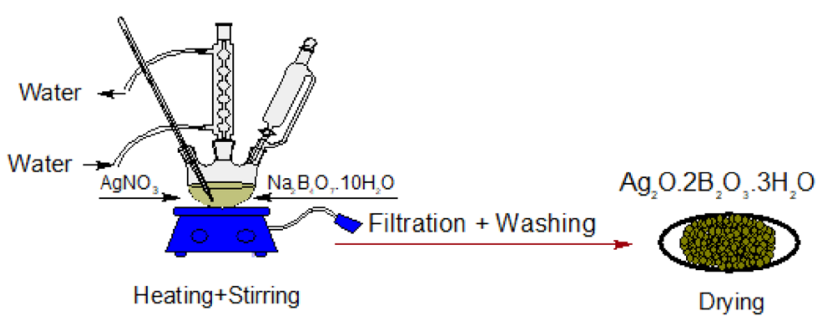

Fig. 1 Synthesis Scheme of AgB13 
absorption spectroscopy using Agilent Cary 60 UV-Vis Spectrophotometer between 200-800 nm.

\section{Results and discussion}

\subsection{Crystallinity and morphology of the NP's}

The phase purity and composition of the obtained silver borate nanoparticles examined by XRD. Figure 2 shows a typical XRD pattern of silver borate nanoparticles, which were compared with its original, hexagonal silver borate structure with JCPDS: $96-150-9895$ peaks. A number of Bragg reflections with $2 \theta$ values of $30.00^{\circ}, 33.20^{\circ}, 33.79^{\circ}$, $34.19^{\circ}, 38.04^{\circ}, 39.21^{\circ}, 43.33^{\circ}, 44.21^{\circ}, 48.99^{\circ}, 52.66^{\circ}, 55.77^{\circ}$, $60.56^{\circ}, 64.31^{\circ}, 66.61^{\circ}$ and $77.32^{\circ}$ are observed corresponding to a typical XRD pattern of silver borate nanoparticles. Since original peaks are almost completely matching with the obtained nanoparticle peaks, we can conclude that nanoparticles with high purity was obtained. All diffraction peaks are indexed according to the Silverborate hexagonal phase. The broadening of the peaks in the $38.04^{\circ}$ and $39.21^{\circ}$ region can be attributed to the small particle size of the synthesized silverborate.

XRD patterns of obtained silver borate structures with different molar ratios of the beginning reactives gave similar XRD patterns as shown in Fig. 3 at $45^{\circ} \mathrm{C}$. Interestingly XRD results showed that increasing the molar ratio of the borax precursor decreased the peak intensity of the obtained particles. This is probably extreme borate anions are regulating the atomic diffusion in the solution by changing the $\mathrm{pH}$, flux rate and proper complex formation.

Therefore nucleation is not occurred as a desired rate which also affects the particle formation. Only the peaks

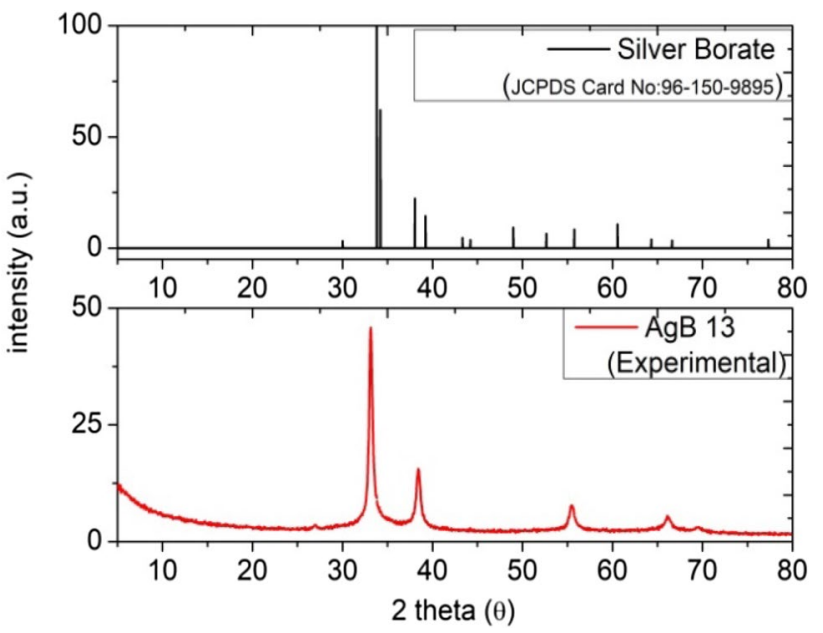

Fig. 2 Comparison of the synthesized $\mathrm{AgB} 13$ and the silver borate in the literature

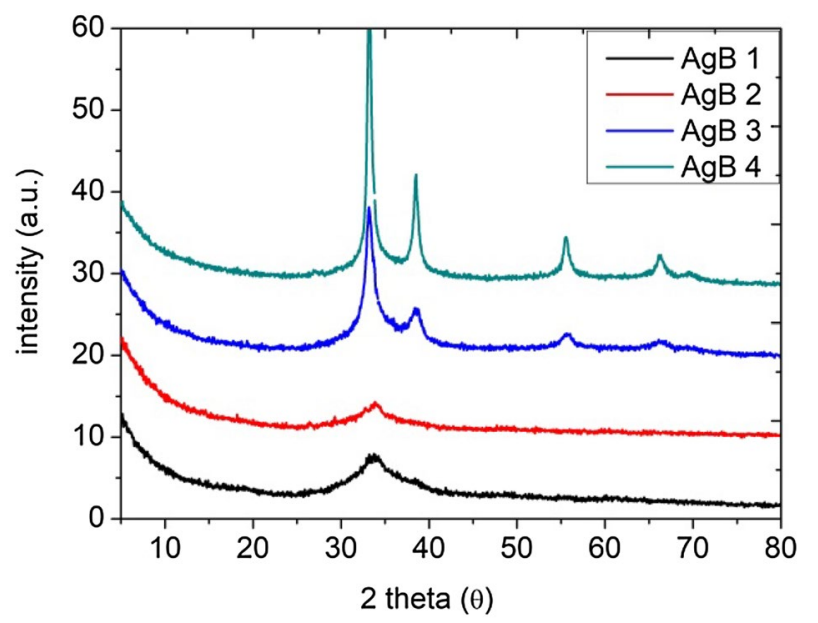

Fig. 3 Silver Borate Formation according to molar ratios at $45^{\circ} \mathrm{C}$

at $33.2^{\circ}, 38.5^{\circ}, 55.6^{\circ}, 66.1^{\circ}$ are noticeable for $\mathrm{AgB}_{4}$ and $\mathrm{AgB}_{3}$ attempts. When compared, decrease or relative modulation of the optimal borate amount led spherical and nanorange products in Fig. 4.

For a further analysis, XRD patterns at the $90{ }^{\circ} \mathrm{C}$ were detected. Therefore, another striking observation is seen at Fig. 5. XRD pattern intensity were significantly enhanced with temperature. Since temperature enhances all the particle formation conditions such as increased saturation in solution, enough flux rate in solution, increased atomic diffusion, highly crystalline structures are formed for a desired growth.

Statistical analysis for the obtained nanoparticles (Fig. 6) showed that size is about $321 \pm 11 \mathrm{~nm}$. 100 particles were counted for examination and size distribution chart was presented in Fig. 6 . It showed the particle size frequencies, an average diameter and a calculated statistical standard deviation acquired with non-linear fitting of the data for the sample.

Chemical structure and atomic analysis using EDX method indicated the presence of $\mathrm{Ag}, \mathrm{B}$ and $\mathrm{O}$ elements of $\mathrm{Ag}_{2} \mathrm{O} \cdot 2 \mathrm{~B}_{2} \mathrm{O}_{3} \cdot 3 \mathrm{H}_{2} \mathrm{O}$ (element $\mathrm{H}$ is omitted) as shown in Fig. 7. No other elements such as sodium was not observed. Furthermore, the quantification of the peaks gives that the atomic ratio of $A g: B: O$ is $2: 4: 10$, which is very close to the stoichiometric $\mathrm{Ag}_{2} \mathrm{O} \cdot 2 \mathrm{~B}_{2} \mathrm{O}_{3} \cdot 3 \mathrm{H}_{2} \mathrm{O}$ nanoparticles.

Since XRD results are completely matching the expected JSPDC standart and SEM images provide information on the established nanoparticles, results are quite convincing for the formation of the Silverborate nanoparticles. 
Fig. 4 Representative SEM image of the Silverborate nanoparticles by different magnification values
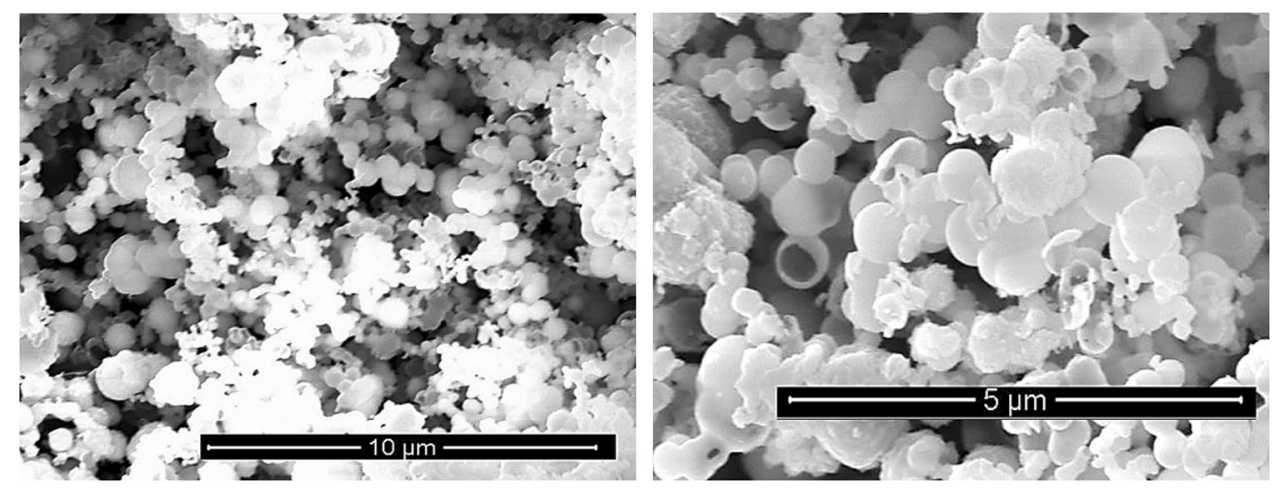

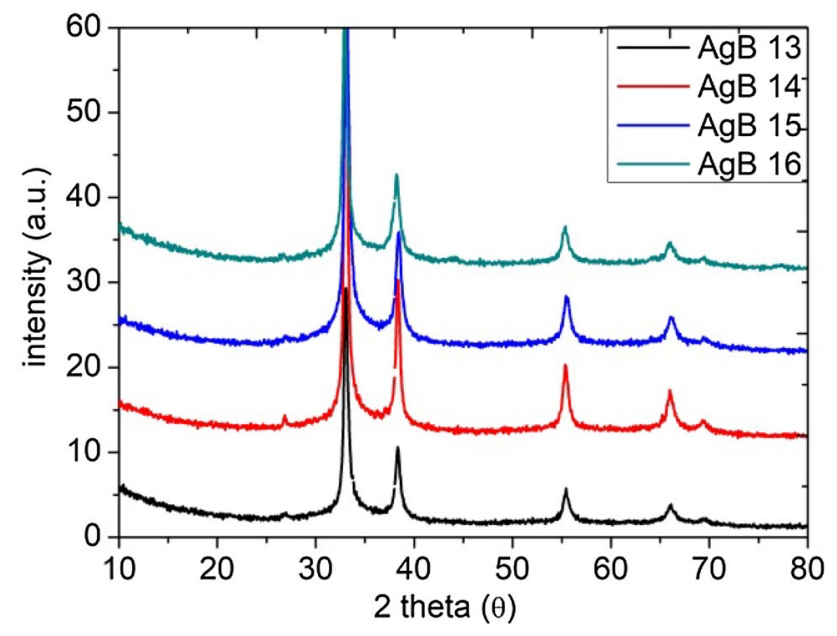

Fig. 5 Silver Borate Formation according to molar ratios at $90^{\circ} \mathrm{C}$

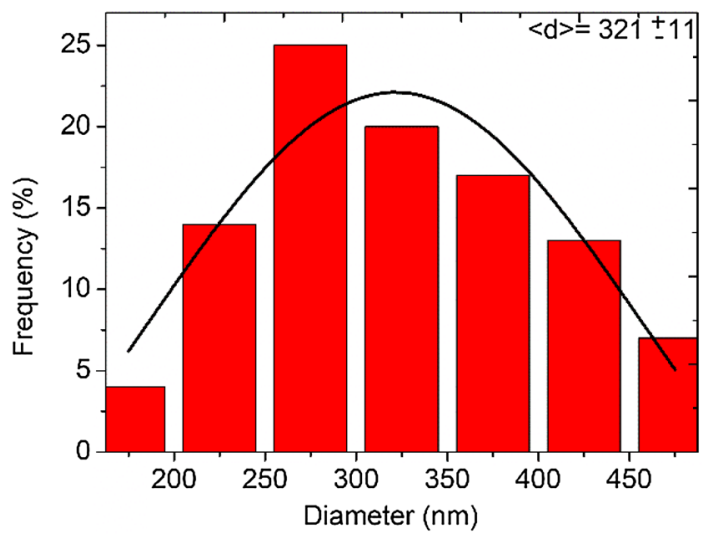

Fig. 6 Particle size distribution of the AgB3 sample

\subsection{Surface characterization}

The FT-IR spectrum of silver borate nanoparticals shown in (Fig. 8). For this analysis dried nanoparticles were used and measurements were directly taken from these nanoparticles. The strong peaks at 890 and $1350 \mathrm{~cm}^{-1}$ are due to the

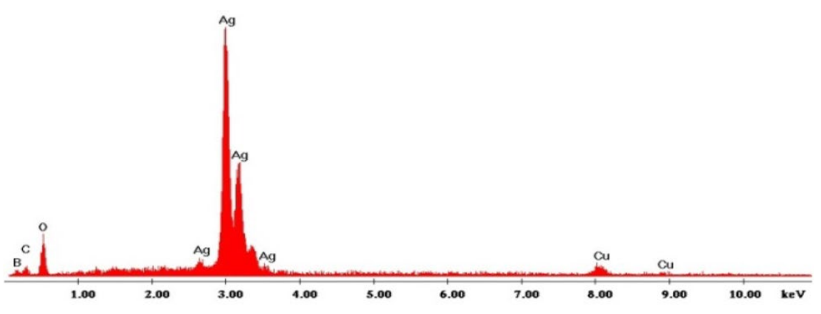

Fig. 7 EDX curve of synthesized AgB13

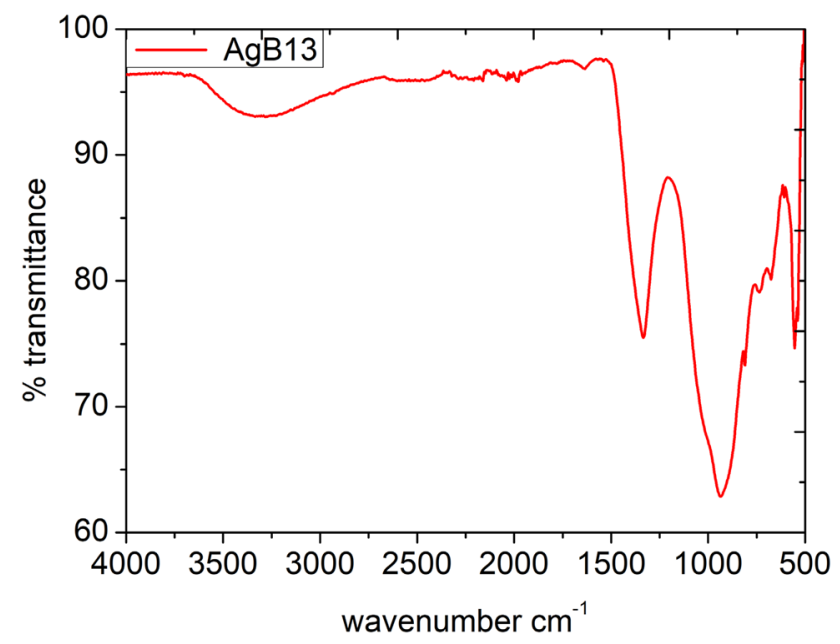

Fig. 8 FTIR curve of synthesized AgB13

B-O stretching of $\mathrm{B}_{4}-\mathrm{O}$ and $\mathrm{B}_{3}-\mathrm{O}$ units respectively $[47,48]$. The bands at $510-590 \mathrm{~cm}^{-1}$ are attributed to the bending of $\mathrm{B}-\mathrm{O}-\mathrm{B}$ linkages in the borate network. The weak band at $1600 \mathrm{~cm}^{-1}$ is assigned to the $\mathrm{H}-\mathrm{O}-\mathrm{H}$ bending mode, which confirms the crystal water in the compound. The band at $3400 \mathrm{~cm}^{-1}$ is the stretching of $\mathrm{O}-\mathrm{H}[51]$.

\subsection{Thermal properties}

TG-DTA profile of the synthesized sample is presented at Fig. 9. From the structure it is clear that only volatile part 


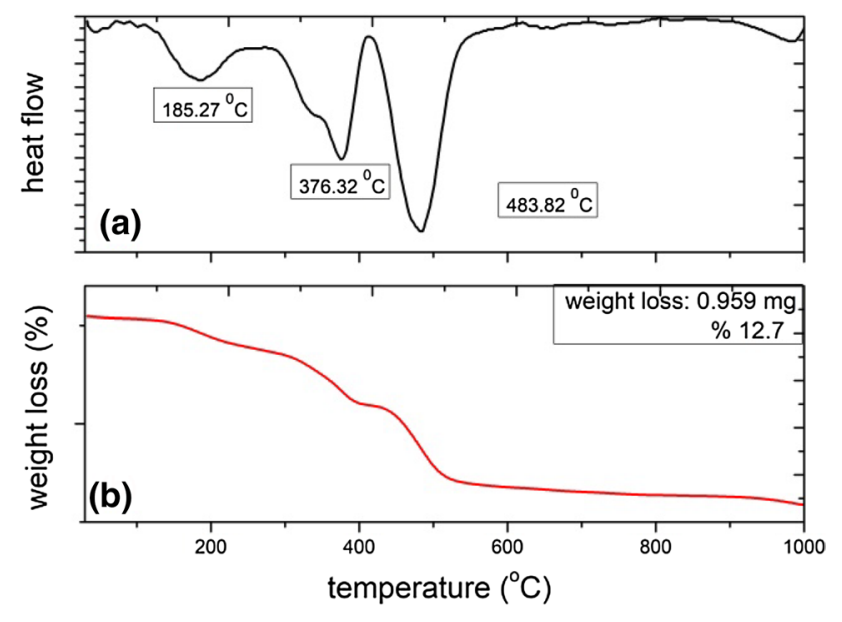

Fig. 9 a DTA curve of synthesized AgB13, b TGA curve of synthesis $\mathrm{AgB13}$

is detected as water structure. Therefore when we define the ratio of removed water with the total amount of beginning material we can also improve and examine the crystal structure of the obtained Silverborate nanoparticles. Total weight loss of $12.70 \mathrm{wt} \%$ was observed which were seen at three different temperatures like 185.27, 376.32 and 483.82 - $\mathrm{C}$ respectively. Since sample was heated from 0 to $1000^{\circ} \mathrm{C}$, corresponding loss of three molar equivalents of the crystal water was detected and could be compared with calculated value of $12 \%$ and formed $\mathrm{Ag}_{2} \mathrm{O} \cdot 2 \mathrm{~B}_{2} \mathrm{O}_{3} \cdot 3 \mathrm{H}_{2} \mathrm{O}$. The Silver Borate compound has slow weight losses before $200^{\circ} \mathrm{C}$, which are related to the release of absorbed water and decomposition of other volatile molecules on the surface of $\mathrm{Ag}_{2} \mathrm{O} \cdot 2 \mathrm{~B}_{2} \mathrm{O}_{3} \cdot 3 \mathrm{H}_{2} \mathrm{O}$. Endothermic peak observed between $185^{\circ} \mathrm{C}$ and $485^{\circ} \mathrm{C}$, which can be ascribed to the loss of molecular water of crystallization.

\subsection{UV-visible analysis}

The absorption spectra of the Silver Borate compound was measured between 200 and $800 \mathrm{~nm}$ at room temperature in Fig. 10. Figure 10 shows the optical absorption spectra of the samples obtained. This compound absorbs photons at approximately $390-400 \mathrm{~nm}$. This is due to the size of the nanoparticles. Additionally surface effects are invisible since there is no significant variation after $400 \mathrm{~nm}$.

\subsection{Antibacterial tests}

The antibacterial activity of Silverborate nanoparticles was demonstrated using Gram-positive Staphylococcus aureus (ATCC 6538) and Gram-negative Escherichia coli (ATCC 25922) bacterial strains. In order to activate stock ATCC cultures stored at $-80^{\circ} \mathrm{C}$, working cultures were established by planting petri-plants containing Nutrient Agar

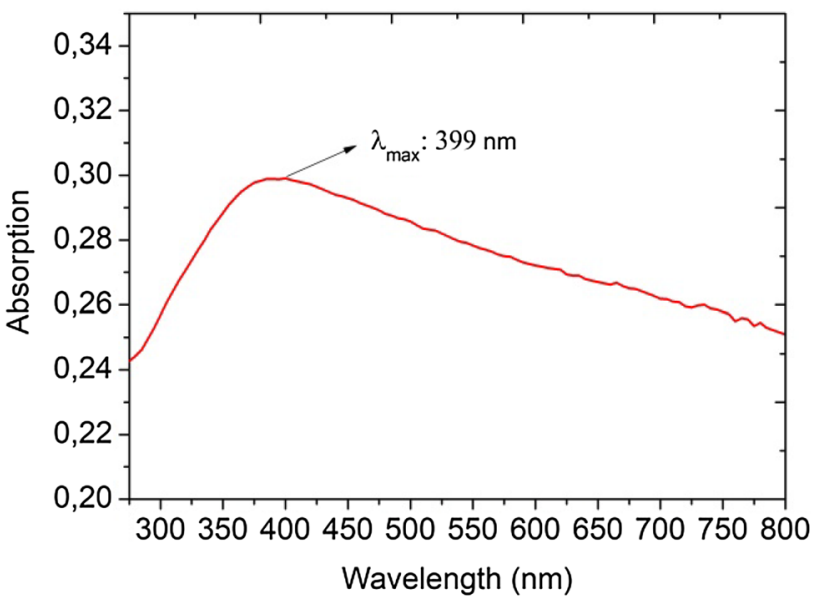

Fig. 10 UV-Visible curve of synthesized AgB13

(Merck). Muller Hinton Broth (MHB) (Merck), a solid nutrient required for the production of bacteria, was utilized to determine the bacterial counts by the "dilution method" for the detection of antibacterial activity of nanomaterials. Nutrient Broth (NB) (Merck) was used for the development of bacterial growth. After $24 \mathrm{~h}$ of incubation at $37^{\circ} \mathrm{C}$, prepared bacterial suspensions were set to $0.5 \mathrm{McF}$ arland turbidity with using sterile PBS.

For the preparation of the ceramic glazes, $1 \%(\mathrm{w} / \mathrm{w})$ nanoparticle were dispersed in the industrial ceramic glaze solution containing $56 \% \mathrm{SiO}_{2}, 14 \% \mathrm{Al}_{2} \mathrm{O}_{3}, 8 \% \mathrm{CaO}$, $2 \% 3 \% \mathrm{Na}_{2} \mathrm{O}, 5 \% \mathrm{SO}_{3}$. The mixture was stirred at $500 \mathrm{rpm}$ for $10 \mathrm{~min}$ for a good dispersion. Then, the surfaces were coated with standard pouring method by covering the surface homogeneously. Obtained wet surfaces were baked at $1200^{\circ} \mathrm{C}$ for $12 \mathrm{~h}$.

The ceramics (Supporting Figure 1) were autoclaved at $121^{\circ} \mathrm{C}$ and $1 \mathrm{~atm}$ pressure for $15 \mathrm{~min}$ and placed in $50 \mathrm{ml}$ centrifuge tubes previously sterilized in $70 \%$ ethanol. Bacterial suspension $\left(10^{7} \mathrm{CFU} \mathrm{ml^{-1 }}\right)$ was added to tubes and incubated at $37^{\circ} \mathrm{C}$ in a shaking incubator at $100 \mathrm{rpm}$ for $24 \mathrm{~h}$. At the end of this period, the bacterial suspension obtained from the samples was diluted and transferred to the agar medium by taking $0.1 \mathrm{ml}$ of the sample and counting bacterial colonies after incubation for $24 \mathrm{~h}$ at $37^{\circ} \mathrm{C}$. Antibacterial activity was used as a control for samples containing only bacterial culture for which no nanomaterials were added. In addition unadditive glaze was also test for antimicrobial activity. Antibacterial activity was determined by the following formula [49].

Antibacterial activity $(\%)=(A-B) / A \times 100$

$A$ is the control sample, and $B$ is the columns taken from the nanomaterials inoculation. According to the results, the ceramic containing AgB13 showed 99.3\% antibacterial 
Fig. 11 Antibacterial Test against Staphylococcus aureus

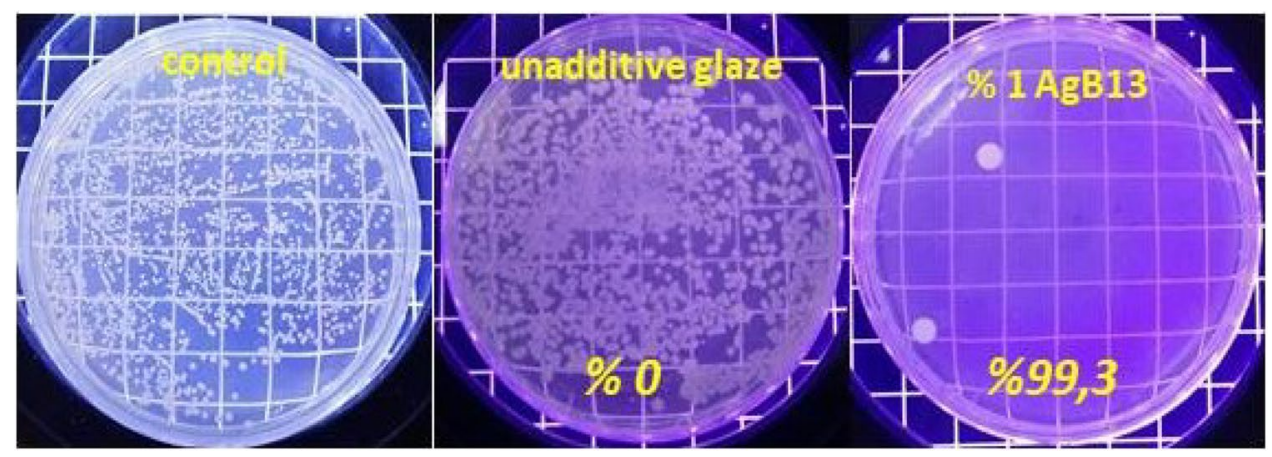

Fig. 12 Antibacterial Test against Escherichia coli

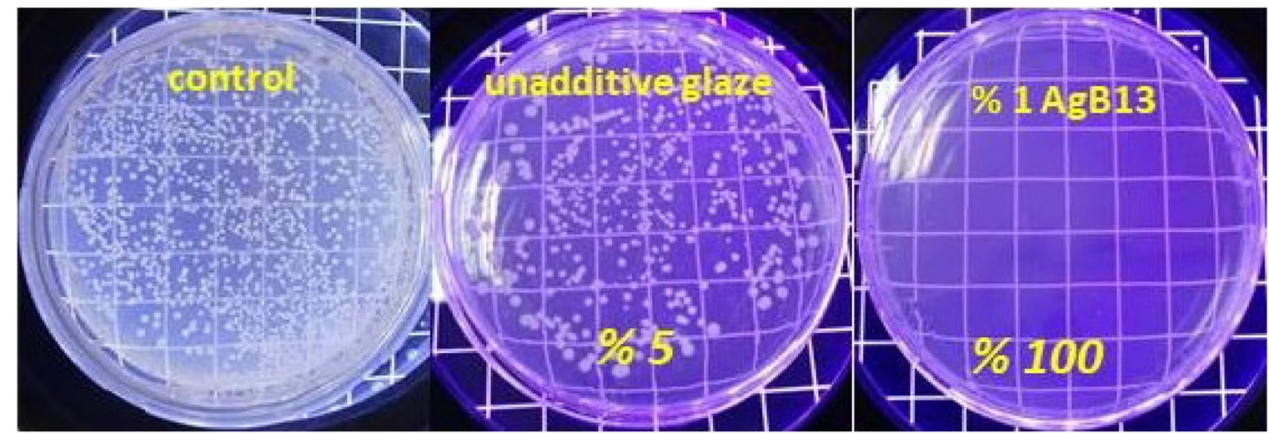

activity against S. aureus (Fig. 11) and 100\% antibacterial activity against $E$. coli (Fig. 12).

\section{Conclusions}

In this study, silver borate nanoparticles having the antibacterial properties were successfully synthesized, characterized and tested as an antibacterial agent.

During the synthesis, four different temperatures, molar ratios and times were varied and obtained structures were analyzed from XRD spectras. With SEM, EDX and TGA analyses structure, shape, morphology and thermal properties of the as-synthesized nanoparticles were determined. SEM images and XRD results confirmed that there is no other impurities and spherical nanoparticles were prcoduced. The antimicrobial effect of the added glaze ceramics on the $\mathrm{Gr}(+)$ and $\mathrm{Gr}(-)$ bacteria was interpreted by applying dilution counting method. The antibacterial effect of the material on the bacteria was calculated by comparing the change in the number of bacteria only in the control with the effect of the nanomaterials produced in the analysis of antibacterial activity.

As a result, unadditive glazed ceramics showed $5 \%$ antibacterial effect on E. coli bacteria and no antibacterial effect showed against $\mathrm{S}$. aureus bacteria. These results show us that there is no antibacterial effect of unadditive glaze. It was concluded that the glazed ceramic containing silver borate compound has antibacterial effect against both $\mathrm{E}$. coli and $\mathrm{S}$. aureus bacteria. While $1 \%$ silver borate added glaze showed $99.3 \%$ antibacterial effect against $\mathrm{S}$. aureus bacteria, the same sample showed $100 \%$ antibacterial effect against E. coli bacteria.

Acknowledgements Support of this work by the Manisa Celal Bayar University Coordination Unit For Scientific Research Projects (BAP) (Project No: 2014-152).

\section{Compliance with ethical standards}

Conflict of interest The authors declare that they have no conflict of interest.

\section{References}

1. Nafiseh B, Fathollah M, Mehdi H (2012) Preparation and antibacterial activity of $\mathrm{Ag} / \mathrm{SiO}_{2}$ thin film on glazed ceramic tiles by sol-gel method. Ceram Int 38(4):2921-2925. https://doi. org/10.1016/j.ceramint.2011.11.068

2. Moritz M, Geszke-Moritz M (2013) The newest achievements in synthesis, immobilization and practical applications of antibacterial nanoparticles. Chem Eng J 228:596-613. https://doi. org/10.1016/j.cej.2013.05.046 
3. Vallée $F$, Ruot B, Bonafous $L$ (2004) Innovative self-cleaning and de-polluting facade surfaces. In: CIB World Building Congress, pp 2-7

4. Daoud WA (2013) Self-cleaning materials and surfaces: a nanotechnology approach, 1st edn. John Wiley \& Sons, New York. ISBN 978-1-119-99177-9

5. Fujishima A, Rao Tata N, Tryk Donald A (2000) Titanium dioxide photocatalysis. J Photochem Photobiol C 1(1):1-21. https://doi. org/10.1016/S1389-5567(00)00002-2

6. Arslan O, Belkoura L, Mathur S (2015) Swift synthesis, functionalization and phase-transfer studies of ultrastable, visible light emitting oleate@ ZnO quantum dots. J Mater Chem C 3:11965

7. Arslan O, Aadesh SP, Belkoura L, Mathur S (2013) Cysteine modified Zwitterionic ZnO Quantum Dots. J Mater Res 28:1946

8. Zhao L, Wang H, Huo K, Cui L, Zhang W, Ni H, Zhang Y, Wu Z, Chu PK (2011) Antibacterial nano-structured titania coating incorporated with silver nanoparticles. Biomaterials 32:5706-5716

9. Ziabka M, Mertas A, Krol W, Bobrowski A, Chlopek J (2012) High density polyethylene containing antibacterial silver nanoparticles for medical applications. Macromol Symp 315:218-225

10. Prombutara P, Kulwatthanasal Y, Supaka N, Sramala I, Chareonpornwattana S (2012) Production of nisin-loaded solid lipid nanoparticles for sustained antimicrobial activity. Food Control 24:184-190

11. Kokura S, Handa O, Takagi T, Ishikawa T, Naito Y, Yoshikawa T (2010) Silver nanoparticles as a safe preservative for use in cosmetics. Nanomedicine 6(4):570-574. https://doi.org/10.1016/j. nano.2009.12.002

12. Panico A, Paladini F, Sannino A, Pollini M (2016) Antibacterial silver treatments on polymeric membranes for fouling control and disinfection in water filtration. J Appl Polym Sci 133:43848. https://doi.org/10.1002/app.43848

13. Matsuyama Hideto (2012) Development of a hydrophilic polymer membrane containing silver nanoparticles with both organic antifouling and antibacterial properties. J Membr Sci 387-388:1-6. https://doi.org/10.1016/j.memsci.2011.06.020

14. Riviera-Garza M, Olguin MT, Garcia-Sosa I, Alcantara D, Rodriguez-Fuentes G (2000) Microporous Mesoporous Mater 39:431-444

15. Kokkoris M, Trapalis CC, Kossionides S, Vlastou R, Nsouli B, Grötzschel R, Spartalis S, Kordas G, Paradellis Th (2002) RBS and HIRBS studies of nanostructured AgSiO2 sol-gel thin coatings. Nucl Instrum Methods Phys Res Sect B 188:67-72

16. Kaegi $R$, Sinnet $B$, Zuleeg $S$, Hagendorfer $H$, Mueller E, Vonbank R, Boller M, Burkhardt M (2010) Release of silver nanoparticles from outdoor facades. Environ Pollut 158:2900-2905

17. Dutta RK, Nenavathu BP, Gangishetty MK, Reddy AVR (2012) Studies on antibacterial activity of ZnO nanoparticles by ROS induced lipid peroxidation. Colloid Surf Sect B 94:143-150

18. Chen R, Cheng G, So MH, Wu J, Lu Z, Che C-M, Sun H (2010) Bismuth subcarbonate nanoparticles fabricated by water-inoil microemulsion-assisted hydrothermal process exhibit antiHelicobacter pylori properties. Mater Res Bull 45:654-658

19. Buckley JJ, Lee AF, Olivi L, Wilson K (2010) Hydroxyapatite supported antibacterial $\mathrm{Ag}_{3} \mathrm{PO}_{4}$ nanoparticles. J Mater Chem 20:8056-8063

20. Dong C, Cairney J, Sun Q, Maddan OL, He G, Deng Y (2010) Investigation of $\mathrm{Mg}(\mathrm{OH})_{2}$ nanoparticles as an antibacterial agent. J Nanopart Res 2(6):2101

21. Yudovin-Farber I, Beyth N, Weiss El, Domb AJ (2010) Antibacterial effect of composite resins containing quaternary ammonium polyethyleneimine nanoparticles. J Nanopart Res 12:591-603

22. Zhou W, Ma Y, Yang H, Ding Y, Luo X (2011) A label-free biosensor based on silver nanoparticles array for clinical detection of serum p53 in head and neck squamous cell carcinoma. Int J Nanomed 6:381-386

23. Arunachalam $R$, Dhansingh $S$, Kalimuthu $B$, Uthirappan $M$, Rose $C$, Mandal AB (2012) Phytosynthesis of silver nanoparticles using Coccinia grandis leaf extract and its application in the photocatalytic degradation. Colloids Surf 94:226-230

24. Giljohann DA, Seferos DS, Daniel WL, Massich MD, Patel PC, Mirkin CA (2010) Gold nanoparticles for biology and medicine. Angew Chem Int Ed 49:3280-3294

25. Chang YN, Zhang M, Xia L, Zhang J, Xing G (2012) The toxic effects and mechanisms of $\mathrm{CuO}$ and $\mathrm{ZnO}$ nanoparticles. Materials 5(12):2850-2871. https://doi.org/10.3390/ma5122850

26. Klasen $\mathrm{HJ}$ (2000) Historical review of the use of silver in the treatment of burns. Burns 26:117-130

27. Olguin MT, Rivera-Garza M, Garcia-Sosa I, Alcantra D, Rodriguez-Fuentes G (2000) Silver supported on natural Mexican zeolite as an antibacterial material. Microporous Mesoporous Mater 39:431-444

28. Top A, Ülkü S (2004) Silver, zinc, and copper exchange in a $\mathrm{Na}$-clinoptilolite and resulting effect on antibacterial activity. Appl Clay Sci 27:13-19

29. Rai M, Yadav A, Gade A (2009) Silver nanoparticles as a new generation of antimicrobials. Biotechnol Adv 27:76-83

30. Franke GG, Nies DH (2001) The product of the ybdE gene of the Escherichia coli chromosome is involved in detoxification of silver ions. Microbiology 147(4):965

31. Morison M, Moffatt C, Bridel-Nixon J, Bale S (1997) A color guide to the nursing management of chronic wounds. Elsevier, New York

32. Rasika Dias HV, Batdorf KH, Fianchini M, Diyabalanage HVK, Carnahan S, Mulcahy R, Rabiee A, Nelson K, van Waasbergen LG (2006) Antimicrobial properties of highly fluorinated silver (I) tris (pyrazolyl) borates. J Inorg Biochem 100:158-160

33. Guggenbichler J-P, Böswald M, Lugauer S, Krall T (1999) A new technology of microdispersed silver in polyurethane induces antimicrobial activity in central venous catheters. Infection 27:16-23

34. Marambio-Jones C, Hoek EMV (2010) A review of the antibacterial effects of silver nanomaterials and potential implications for human health and the environment. J. Nanoparticles Res. 12:1531-1551

35. Laga M, Meheus A, Piot P (1989) Epidemiology and control of gonococcal ophthalmia neonatorum. Bull World Health Org 67:471-477

36. Tokumaru T, Shimiziu Y, Fox C (1974) Evaluation of antifungal activity of silver nanoparticles on Fusarium oxysporum. Res Commun Chme Pathol Pharmacol 8:151-158

37. McLean RJ, Hussain A, Sayer M, Vincent PJ, Hughes DJ, Smith TJ (1993) Antibacterial activity of multilayer silver-copper surface films on catheter material. Can J Microbiol 39:895-899

38. Saint S, Elmore JG, Sullivan SD, Emerson SS, Koepsell TD (1998) The efficacy of silver alloy-coated urinary catheters in preventing urinary tract infection: a meta-analysis. Am J Med 105(3):236-241

39. Kawahara K, Tsuruda K, Morishita M, Uchida M (2000) Antibacterial effect of silver-zeolite on oral bacteria under anaerobic conditions. Dent Mater 16:452-455

40. Duran N, Marcato PD, De Conti R, Alves OL, Costa FTM, Brocchi M (2010) Potential use of silver nanoparticles on pathogenic bacteria, their toxicity and possible mechanisms of action. J Braz Chem Soc 21:949-959

41. Davies RL, Etris SF (1997) The development and functions of silver in water purification and disease control. Catal Today 36:107-114

42. Yamanaka M, Hara K, Kudo J (2005) Bactericidal actions of a silver ion solution on Escherichia coli, studied by energy-filtering 
transmission electron microscopy and proteomic analysis. Appl Environ Microbiol 71:7589-7593

43. Ahearn DG, May LL, Gabriel MM (1995) Adherence of organisms to silver-coated surfaces. J Ind Microbiol 15:372-376

44. Sadeghnejad A, Aroujalian A, Sharhzad Fazel AR (2014) Antibacterial nano silver coating on the surface of polyethylene films using corona discharge. Surf Coat Technol 245:1-8

45. Magyari K, Stefanc R, Vodnar DC, Vulpoi A, Baia L (2014) The silver influence on the structure and antibacterial properties of the bioactive $10 \mathrm{~B}_{2} \mathrm{O}_{3}-30 \mathrm{Na}_{2} \mathrm{O}-60 \mathrm{P}_{2} \mathrm{O}_{2}$ glass. J Non-Cryst Solids 402:182-186

46. Jaiswal S, McHaleb P, Duffya B (2012) Preparation and rapid analysis of antibacterial silver, copper and zinc doped sol-gel surfaces. Colloids Surf B 94:170-176

47. RalucaCiceo-Lucacel IoanArdelean (2007) FT-IR and Raman study of silver lead borate-based glasses. J Non-Cryst Solids
353(18-21):2020-2024. https://doi.org/10.1016/j.jnoncrysol .2007 .01 .066

48. Gao X, Guo Y, Tian Y, Li S, Zhou S, Wang Z (2011) Synthesis and characterization of polyurethane/zinc borate nanocomposites. Colloids Surf A Physicochem Eng Asp 384:2-8

49. Keskin NOS, Kılıç NK, Dönmez G, Tekinay T, (2016) Green synthesis of silver nanoparticles using cyanobacteria and evaluation of their photocatalytic and antimicrobial activity. J Nano Res 40:120

Publisher's Note Springer Nature remains neutral with regard to jurisdictional claims in published maps and institutional affiliations. 